\title{
Cerebellar T2 hyperintensities in a patient with tremor
}

\section{Figure $\quad$ MR images}

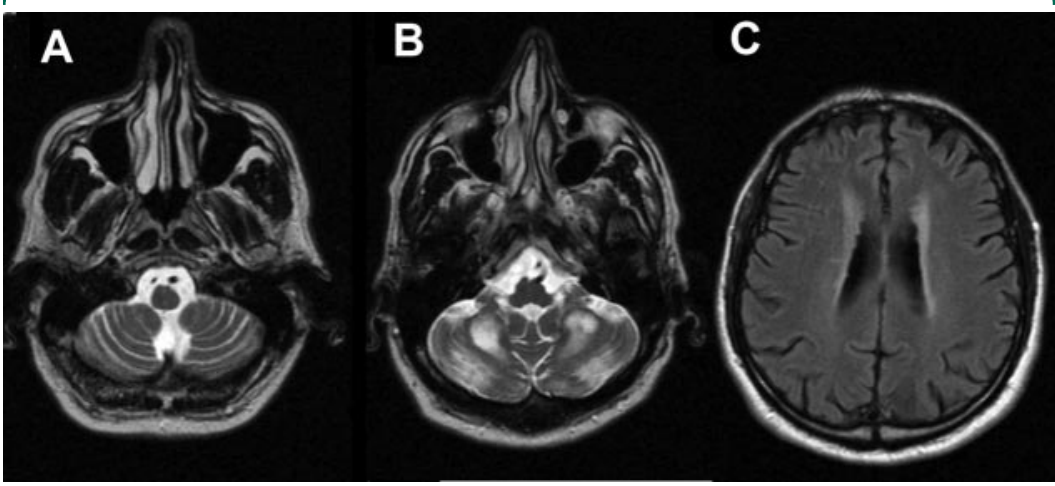

(A) T2-weighted MR image showing moderate cerebellar volume loss. (B) T2-weighted MR image showing marked hyperintensity in the middle cerebellar peduncles extending into the posterior white matter of the cerebellum. (C) Axial FLAIR MR image through the level of the lateral ventricles showing cerebral periventricular hyperintensities.

A 58-year-old man noticed mild hand tremor for 2 years. As the tremor increased, he was referred to brain CT and consequently to MRI showing cerebellar and cerebral hyperintense areas on T2weighted images (figure). Neurologic examination was normal except for mild postural and intentional tremor, more pronounced on the left hand. Because of the typical, ${ }^{1,2}$ though not specific, ${ }^{3}$ radiologic features, diagnosis of fragile X premutation tremor/ataxia syndrome (FXTAS) was subsequently confirmed by finding a CGG repeat number of 100 on genetic study. This case illustrates the wide spectrum of clinical features of FXTAS and the necessity for high suspicion even in monosymptomatic adults.

Menachem Sadeh, MD, Holon, Israel; Alexander Lossos, MD, Jerusalem, Israel

Disclosure: The authors report no conflicts of interest.

Address correspondence and reprint requests to Dr. M. Sadeh, Department of Neurology, Wolfson Medical Center, Holon, Israel, mesadeh@post.tau.ac.il

1. Jacquemont S, Hagerman RJ, Leehey M, et al. Fragile X premutation tremor/ataxia syndrome: molecular, clinical, and neuroimaging correlates. Am J Hum Genet 2003;72: 869-878.

2. Berry-Kravis E, Abrams L, Coffey SM, et al. Fragile X-associated tremor/ataxia syndrome: clinical features, genetics, and testing guidelines. Mov Disord 2007;22:2018-2030.

3. Storey E, Billimoria P. Increased T2 signal in the middle cerebellar peduncles on MRI is not specific for fragile X premutation syndrome. J Clin Neurosci 2005;12: 42-43. 


\section{Neurology}

\section{Cerebellar T2 hyperintensities in a patient with tremor \\ Menachem Sadeh and Alexander Lossos \\ Neurology 2008;70;578 \\ DOI 10.1212/01.wnl.0000299191.34969.9a}

This information is current as of February 11, 2008

Updated Information \&

Services

References

Subspecialty Collections

Permissions \& Licensing

Reprints including high resolution figures, can be found at:

http://n.neurology.org/content/70/7/578.full

This article cites 3 articles, 0 of which you can access for free at: http://n.neurology.org/content/70/7/578.full\#ref-list-1

This article, along with others on similar topics, appears in the following collection(s):

Cerebellum

http://n.neurology.org/cgi/collection/cerebellum

MRI

http://n.neurology.org/cgi/collection/mri

Tremor

http://n.neurology.org/cgi/collection/tremor

Trinucleotide repeat diseases

http://n.neurology.org/cgi/collection/trinucleotide_repeat_diseases

Information about reproducing this article in parts (figures,tables) or in its entirety can be found online at:

http://www.neurology.org/about/about_the_journal\#permissions

Information about ordering reprints can be found online:

http://n.neurology.org/subscribers/advertise

Neurology ${ }^{\circledR}$ is the official journal of the American Academy of Neurology. Published continuously since 1951, it is now a weekly with 48 issues per year. Copyright . All rights reserved. Print ISSN: 0028-3878. Online ISSN: 1526-632X.

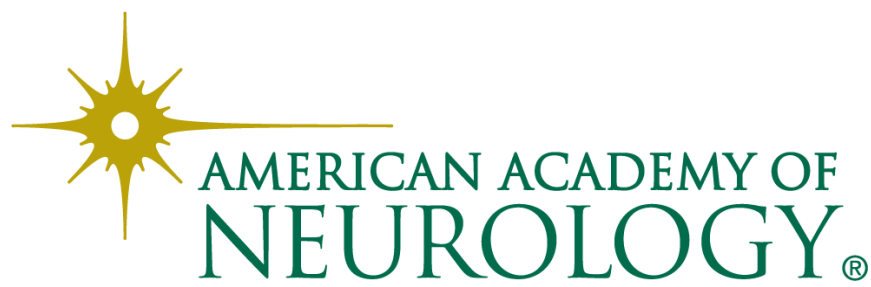

